\title{
The effect of cold ischemic time on the immunohistochemical evaluation of estrogen receptor, progesterone receptor, and HER2 expression in invasive breast carcinoma
}

\author{
Isil Z Yildiz-Aktas, David J Dabbs and Rohit Bhargava \\ Department of Pathology, Magee-Womens Hospital, University of Pittsburgh Medical Center, \\ Pittsburgh, PA, USA
}

\begin{abstract}
The American Society of Clinical Oncology/College of American Pathologist (ASCO/CAP) guidelines on breast cancer currently recommend a cold ischemic time of $<1 \mathrm{~h}$, although data are limited. Breast resection specimens were subjected to variable cold ischemic time periods $(0.5,1,2,3,4,24$, and $48 \mathrm{~h})$ within the refrigerator and at room temperature. The study included 25 tumors, all of which had refrigerated samples. Nonrefrigerated samples (samples at room temperature) were present on 23 cases. Hormone receptors were semiquantitatively scored using the H-score method. Human epidermal growth factor receptor 2 gene ERBB2 (HER2) was scored using the ASCO/CAP guidelines. The results were compared with the core biopsy scores, which have negligible cold ischemic time period before fixation. Mild reduction in staining for hormone receptors was judged present if the $\mathrm{H}$-score on the resection specimen was between one-half and three-fourth of the $\mathrm{H}$-score at core biopsy. Significant reduction was judged present when the H-score on resection was less than one-half of the core biopsy $\mathrm{H}$-score. Mild reduction in HER2 staining was judged present if there was one-step reduction; and significant reduction was judged present if there was two-step reduction in staining. A true reduction was judged present only when the reduction was consistently present for the increasing time interval. A focal reduction for a particular time sample was attributed to the heterogeneity of the tumor sample. Non-refrigerated samples are affected more by prolonged cold ischemic time than refrigerated samples. Cold ischemic time period of as short as one-half hour may occasionally impact the immunohistochemical (IHC) staining for progesterone receptor. Significant reduction in IHC staining for hormone receptors, and HER2, however, generally does not result until $4 \mathrm{~h}$ for refrigerated samples and $2 \mathrm{~h}$ for non-refrigerated samples. The ASCO/CAP guideline of cold ischemic time period of $<1 \mathrm{~h}$ is a prudent guideline to follow.

Modern Pathology (2012) 25, 1098-1105; doi:10.1038/modpathol.2012.59; published online 30 March 2012
\end{abstract}

Keywords: breast carcinoma; cold ischemic time; ER/PR/HER2

All invasive primary breast cancers are analyzed for at least estrogen receptor (ER), progesterone receptor (PR), and human epidermal growth factor receptor 2 gene ERBB2 (HER2), as these markers have been shown to be the most important prognostic and predictive factors in breast cancer. The patients with ER + primary invasive breast cancer derive considerable benefit from endocrine therapy, while

Correspondence: Dr R Bhargava, MD, Department of Pathology, Magee-Womens Hospital of UPMC, 300 Halket Street, Pittsburgh, PA 15213, USA.

E-mail: rbhargava@mail.magee.edu

Received 4 January 2012; revised 5 February 2012; accepted 5 February 2012; published online 30 March 2012
ER-negative tumors do not. Similarly to ER expression, PR expression by immunohistochemistry also provides prognostic and predictive information. ${ }^{1,2}$ Accurate determination of biomarkers is essential for the proper management of breast cancer patients. $^{3-8}$ The HER2 is overexpressed in $\sim 15-20 \%$ of breast carcinomas. ${ }^{9-11}$ HER2 positivity is associated with higher rate of recurrence and mortality in newly diagnosed breast cancer patients, and agents that target HER2 are found to be effective in both the metastatic and adjuvant settings, reducing the risk of recurrence and mortality in patients with early stage disease. This makes HER2 overexpression analysis a standard of care and another useful marker for therapeutic decision making in breast cancer. ${ }^{12-14}$ 
Tissue handling is one of the key pre-analytic variables that must be controlled according to the recent American Society of Clinical Oncology/ College of American Pathologist (ASCO/CAP) guidelines. ${ }^{15}$ The progressive loss of activity of labile macromolecules after the surgical interruption of blood flow leading to tissue ischemia, acidosis, and enzymatic degradation has been documented. ${ }^{16-20}$ The warm and cold ischemic times are accepted as important variables in the analysis of these macromolecules from clinical tissue samples. While it is not possible to control the warm ischemic time, cold ischemic time can be controlled with proper specimen handling. The standardization of cold ischemic time, which is the time between tissue removal and the initiation of formalin permeation of the tissue, is an important step to help ensure that differences in levels of protein expression for clinically relevant targets such as ER, PR, and HER2 are biologically meaningful and are not an artifact related to the manner in which the tissue was handled. ${ }^{15}$

The current recommendation is to fix the breast resection specimen as quickly as possible in an adequate volume of fixative, to record the time of tissue collection, which is the time that the tissue is handed off and the time the tissue is placed in fixative, in order to document the time to fixation of the specimen. ${ }^{15}$ The time from tumor removal to fixation should be kept to $\leq 1 \mathrm{~h}$ to comply with these recommendations. There is limited literature on the effects of delayed formalin fixation on ER, PR, and HER2 immunohistochemical (IHC) status. The specific aim of this study was to examine the impact of cold ischemic time on biomarker testing of invasive breast cancer samples.

\section{Materials and methods}

Tumor tissues were collected prospectively from invasive breast carcinomas resected at our institution within the past 1.5 years. All resection samples were collected from the operating rooms. The cases included in this study were not consecutive cases. Breast cancer specimens from patients who received neoadjuvant chemotherapy were excluded. Breast resection specimens that had more than sufficient tumor available for diagnostic purposes on gross inspection were considered for this study. Therefore, only large tumors (mostly $>2 \mathrm{~cm}$ ) were considered, as several tumor pieces from the same case were subjected to variable cold ischemic time periods $(0.5,1,2,3,4,24$, and $48 \mathrm{~h})$ within the refrigerator and at room temperature. Subsequently, the collected tissues were placed in $10 \%$ neutral phosphate-buffered formalin for 8-48 h before processing. Thereafter, tissue processing, embedding, sectioning, and staining were identical to other routine specimens. There was no change in our laboratory IHC protocols for this particular study; ie, pre-treatment, antigen retrieval, and staining platform were identical to those used for breast core biopsies.

The study included 25 cases, all of which had refrigerated samples. Non-refrigerated samples (samples at room temperature) were present on 23 cases. In addition to an H\&E section, the study tissues were stained for ER, PR, and HER2. ER was assessed using antibody clone SP1 (Ventana, Tucson, AZ) and performed using the IVIEW detection on the Benchmark XT (Ventana). PR was assessed using antibody clone 1E2 (Ventana), and performed using the IVIEW detection on the Benchmark XT. HER2 protein was analyzed and scored using 4B5 antibody (Ventana) with IVIEW detection on the Benchmark XT. All cases were scored by one pathologist (RB).

Both qualitative and semi-quantitative analyses were performed for hormone receptors. Qualitative scoring was performed using ASCO/CAP criteria, ie, $1 \%$ cells with weak staining considered as positive for ER and PR. Semi-quantitative scoring for ER and PR was performed using the H-score method. ${ }^{21,22}$ The $\mathrm{H}$-score is given as the sum of the percent staining multiplied by an ordinal value corresponding to the intensity level $(0=$ none, $1=$ weak, $2=$ moderate, and $3=$ strong). With four intensity levels, the resulting score ranges from 0 (no staining in the tumor) to 300 (diffuse intense staining of the tumor). Mild reduction in staining for hormone receptors was judged present if the H-score on the resection specimen was between one-half and three-fourth of the H-score at core biopsy. Significant reduction was judged present when the $\mathrm{H}$-score on resection was less than one-half of the core biopsy H-score. HER2 was qualitatively/semi-quantitatively scored using the ASCO/CAP guidelines, ie, HER2 scored as negative (IHC score 0 and $1+$ ), equivocal (IHC score $2+$ ), and positive (IHC score $3+$ ). Mild reduction in HER2 staining was judged present if there was onestep discordance (in IHC score) and significant reduction was judged present if there was two-step reduction in staining. The results were compared with the core biopsy scores, which have negligible cold ischemic times.

Concurrent with the resected study specimen, the prior diagnostic core biopsy that had been previously stained for ER/PR/HER2 using identical antibodies was also reviewed and rescored by the same pathologist (RB), but with a washout time interval of several hours. A true reduction was judged present only when the reduction was consistently present for the increasing time interval. A focal reduction for a particular time sample was attributed to the heterogeneity of the tumor sample.

The difference in mean $\mathrm{H}$-scores between core biopsy samples and $\mathrm{H}$-scores for different cold ischemic time periods was calculated using unpaired $t$-test (GraphPad Software, La Jolla, CA). A two-tailed $P$-value of $<0.05$ was considered as statistically significant. 


\section{Results}

The study included 25 cases, all of which had refrigerated samples. Non-refrigerated samples (samples at room temperature) were present on 23 cases. Four cases were negative for ER and PR on core biopsy, but these were included in the study because HER2 score on these cases was not 0 .

Of the 25 refrigerated samples, $8(32 \%), 6(24 \%)$, and $6(24 \%)$ cases showed reduction for ER, PR, and HER2 expression, respectively. Details of degree of reduced staining are shown in Table 1 . Of the 23 non-refrigerated (room temperature) samples, 11 (48\%), 10 (43\%), and $11(48 \%)$ cases showed reduction for ER, PR, and HER2 expression, respectively. Details of degree of reduced staining are shown in Table 2. Examples of reduced staining secondary to prolonged cold ischemic time for ER, PR, and HER2 are shown in Figures 1, 2, and 3, respectively.

On 23 cases that had both refrigerated and nonrefrigerated samples, further analysis was performed by comparing the mean and median ER/PR H-scores of delayed fixation samples to corresponding core biopsies. The mean and median ER H-scores for core biopsy samples were 210 and 250 , respectively. The mean and median PR H-scores for core biopsy samples were 132 and 125, respectively. The mean and median ER and PR H-scores for different cold ischemic time periods on refrigerated and nonrefrigerated samples are shown in Tables 3 and 4,

Table 1 The details of reduction in staining for ER, PR, and HER2 secondary to prolonged cold ischemic time on refrigerated samples

\begin{tabular}{|c|c|c|}
\hline & $\begin{array}{l}\text { Reduction } \\
\text { in staining }\end{array}$ & Details \\
\hline $\begin{array}{l}\text { Estrogen } \\
\text { receptor }\end{array}$ & $\begin{array}{c}8 / 25 \\
(32 \%)\end{array}$ & $\begin{array}{l}\text { Two cases: mild reduction at } 48 \mathrm{~h} \text { only } \\
\text { Two cases: mild reduction at } 4 \mathrm{~h} \text {; } \\
\text { significant reduction at } 24 \text { and } 48 \mathrm{~h} \\
\text { Two cases: significant reduction } \\
\text { at } 48 \mathrm{~h} \\
\text { One case: significant reduction at } \\
24 \text { and } 48 \mathrm{~h} \\
\text { One case: significant reduction at } \\
4,24 \text {, and } 48 \mathrm{~h}\end{array}$ \\
\hline $\begin{array}{l}\text { Progesterone } \\
\text { receptor }\end{array}$ & $\begin{array}{c}6 / 25 \\
(24 \%)\end{array}$ & $\begin{array}{l}\text { Two cases: mild reduction at } 48 \mathrm{~h} \text { only } \\
\text { Two cases: mild reduction at } 4 \mathrm{~h} ; \\
\text { significant reduction at } 24 \text { and } 48 \mathrm{~h} \\
\text { One case: significant reduction at } 48 \mathrm{~h} \\
\text { only } \\
\text { One case: significant reduction at } 4 \text {, } \\
24 \text {, and } 48 \mathrm{~h}\end{array}$ \\
\hline $\begin{array}{l}\text { HER2 } \\
\text { protein }\end{array}$ & $\begin{array}{c}6 / 25 \\
(24 \%)\end{array}$ & $\begin{array}{l}\text { Two cases: mild reduction at } 48 \mathrm{~h} \text { only } \\
\text { One case: mild reduction at } 24 \text { and } \\
48 \mathrm{~h} \\
\text { Two cases: mild reduction at } 4,24 \text {, } \\
\text { and } 48 \mathrm{~h} \\
\text { One case: mild reduction at } 4 \text { and } \\
24 \mathrm{~h} \text {; } \\
\text { significant reduction at } 48 \mathrm{~h}\end{array}$ \\
\hline
\end{tabular}

respectively. Although the difference in mean H-scores (compared with core biopsy) did not reach statistical significance for refrigerated samples (Table 3 ), the mean $\mathrm{H}$-scores progressively reduced at a clinically significant level, especially for PR, from $4 \mathrm{~h}$ onward. In contrast, the reduction in mean $\mathrm{H}$-scores was more marked in non-refrigerated samples and the difference (compared with core biopsy) became statistically significant at $3 \mathrm{~h}$ for ER and $24 \mathrm{~h}$ for PR (Table 4).

We also analyzed the samples qualitatively to see if any sample converted from a positive to a negative result. In refrigerated samples, two cases became negative for ER (one at $24 \mathrm{~h}$ and one at $48 \mathrm{~h}$ ) and three cases became negative for PR (two cases at $48 \mathrm{~h}$

Table 2 The details of reduction in staining for ER, PR, and HER2 secondary to prolonged cold ischemic time on non-refrigerated (at room temperature) samples

\begin{tabular}{|c|c|c|}
\hline & $\begin{array}{l}\text { Reduction } \\
\text { in staining }\end{array}$ & Details \\
\hline $\begin{array}{l}\text { Estrogen } \\
\text { receptor }\end{array}$ & $\begin{array}{l}11 / 23 \\
(48 \%)\end{array}$ & $\begin{array}{l}\text { One case: mild reduction at } 48 \mathrm{~h} \text { only } \\
\text { One case: mild reduction at } 24 \mathrm{~h} \text {; } \\
\text { significant reduction at } 48 \mathrm{~h} \\
\text { Two cases: mild reduction at } \\
3 \text { and } 4 \mathrm{~h} \text {; } \\
\text { significant reduction at } 24 \text { and } 48 \mathrm{~h} \\
\text { One case: mild reduction at } 2 \text { and } 3 \mathrm{~h} \text {; } \\
\text { significant reduction at } 4,24 \text {, and } 48 \mathrm{~h} \\
\text { Two cases: significant reduction at } 24 \\
\text { and } 48 \mathrm{~h} \\
\text { One case: significant reduction at } 4 \text {, } \\
24 \text {, and } 48 \mathrm{~h} \\
\text { Two cases: significant reduction at } 3 \text {, } \\
4,24 \text {, and } 48 \mathrm{~h} \\
\text { One case: significant reduction at } 2,3 \text {, } \\
4,24 \text {, and } 48 \mathrm{~h}\end{array}$ \\
\hline
\end{tabular}

Progesterone 10/23 One case: mild reduction at $48 \mathrm{~h}$ only receptor $\quad(43 \%) \quad$ One case: mild reduction at 24 and $48 \mathrm{~h}$

One case: mild reduction at $4 \mathrm{~h}$; significant reduction at 24 and $48 \mathrm{~h}$ One case: mild reduction at 3 and $4 \mathrm{~h}$; significant reduction at 24 and $48 \mathrm{~h}$ One case: mild reduction at $3 \mathrm{~h}$; significant reduction at 4,24 , and $48 \mathrm{~h}$ One case: mild reduction at $0.5,1,2$, 3 , and $4 \mathrm{~h}$;

significant reduction at 24 and $48 \mathrm{~h}$

One case: significant reduction at 24 and $48 \mathrm{~h}$

Two cases: significant reduction at $3,4,24$, and $48 \mathrm{~h}$

One case: significant reduction at 2, 3, 4,24 , and $48 \mathrm{~h}$

$\begin{array}{lr}\text { HER2 } & 11 / 23 \\ \text { protein } & (48 \%)\end{array}$

Five cases: mild reduction at $48 \mathrm{~h}$ only

Two cases: mild reduction at 24 and $48 \mathrm{~h}$

Two cases: mild reduction at 3, 4, 24, and $48 \mathrm{~h}$

One case: mild reduction at $4 \mathrm{~h}$; significant reduction at 24 and $48 \mathrm{~h}$ One case: mild reduction at 3 and $4 \mathrm{~h}$; significant reduction at 24 and $48 \mathrm{~h}$ 


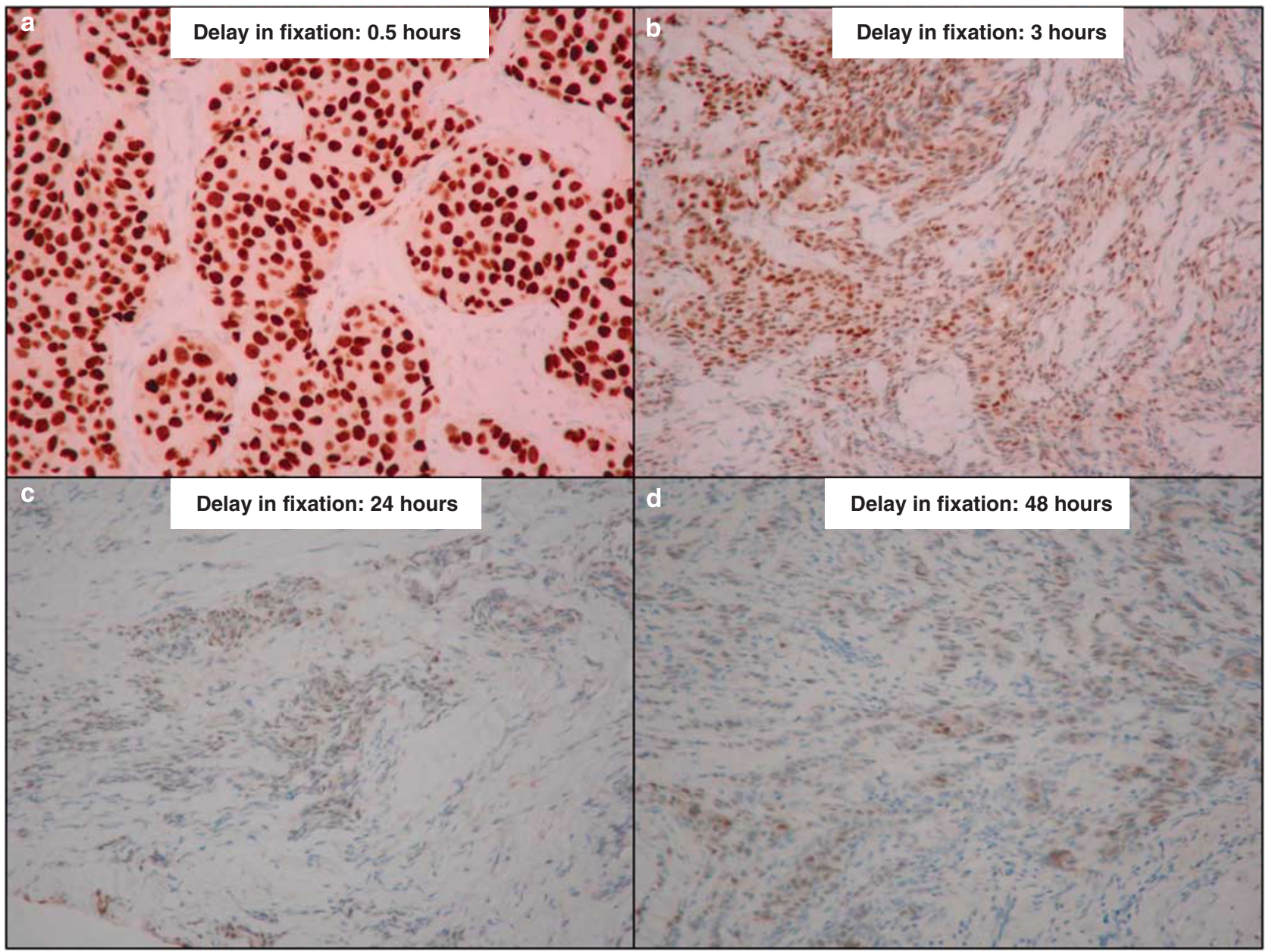

Figure 1 An example of a non-refrigerated case. The tumor was strongly positive for estrogen receptor (similarly to core biopsy) at $0.5 \mathrm{~h}$ of

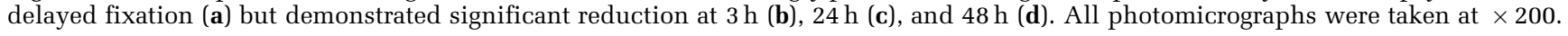

and one case at $24 \mathrm{~h}$ ). In non-refrigerated samples, one case became negative for ER (at $24 \mathrm{~h}$ ) and three cases became negative for PR (one case at $4 \mathrm{~h}$, one case at $24 \mathrm{~h}$, and one case at $48 \mathrm{~h}$ ). There was only one HER2 3 + case, and this case showed same expression in both refrigerated and non-refrigerated samples for all time periods. Among the HER2 $2+$ cases, one case showed one-step reduction starting at $4 \mathrm{~h}$ on refrigerated samples. In contrast, six cases showed one- to two-step reduction for non-refrigerated samples (two cases starting at $3 \mathrm{~h}$, one case at $4 \mathrm{~h}$, one case at $24 \mathrm{~h}$, and two cases at $48 \mathrm{~h}$ ).

\section{Discussion}

Hormone receptor expression remains the most important biomarker in breast cancer and is the cornerstone of optimal individual patient treatment decisions. The specific aim of this study was to examine the impact of cold ischemic time on biomarker testing of invasive breast cancer samples. The warm and cold ischemic times are widely accepted as important variables in the analysis of labile macromolecules such as proteins, RNA, and DNA from clinical tissue samples. Warm ischemic time is the time from the interruption of the blood supply to the tumor by the surgeon to the excision of the tissue specimen, whereas cold ischemic time is the time from excision to the initiation of tissue fixation. Numerous studies have documented the progressive loss of activity of labile molecules after the surgical interruption of blood flow. ${ }^{16-20}$ The standardization of cold ischemic time is important and is a modifiable factor in proper assessment of biomarkers. The pathologist should effectively communicate this priority to all members of the breast care management team so processes are put in place to make sure the time of tissue collection, and the fixation start time is routinely recorded.

Prolonged tumor ischemia induced by delays in formalin fixation is known to cause decreased ER and PR expression. Uy et $a l^{23}$ in their study of 160 consecutive patients accrued to an adjuvant hormonal therapy clinical trial between March 2003 and May 2008, compared ER and PR protein assays of tissues from modified radical mastectomy specimens 


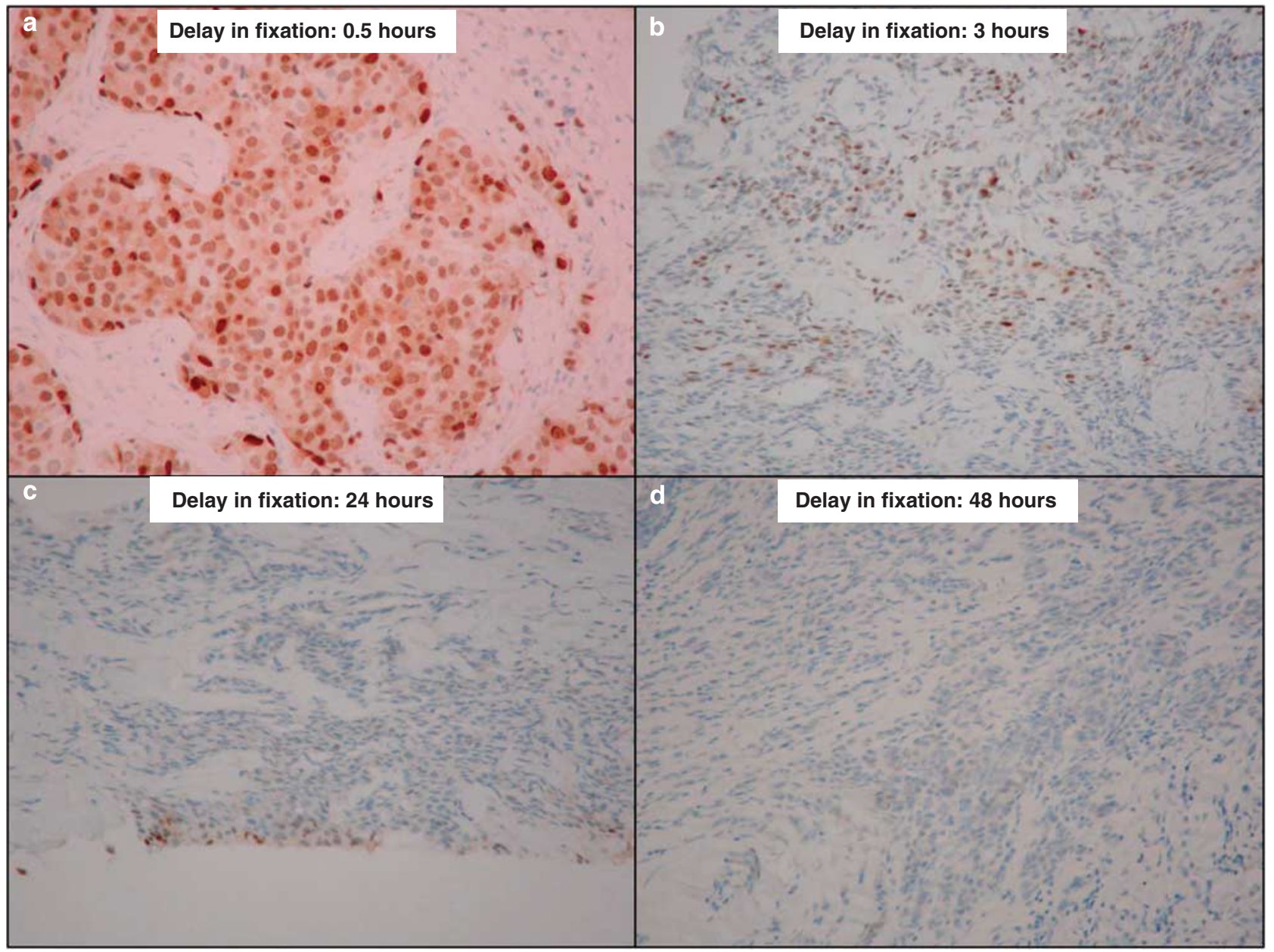

Figure 2 Same case as Figure 1. The tumor showed moderate reactivity for progesterone receptor (similarly to core biopsy) at $0.5 \mathrm{~h}$ of delayed fixation (a), but demonstrated significant reduction at $3 \mathrm{~h}(\mathbf{b})$. Only rare cells at the tissue edge stained for progesterone receptor at $24 \mathrm{~h}(\mathbf{c})$, and the tumor was completely negative at $48 \mathrm{~h}(\mathbf{d})$. All photomicrographs were taken at $\times 200$.

to their prior core needle biopsy ER and PR IHC assay results. They found that core needle biopsy specimens were associated with more frequent and higher levels of tumoral hormonal receptor proteins than modified radical mastectomy specimens. They concluded that delayed fixation of modified radical mastectomy tissues likely accounted for this finding and optimal selection of patients for hormonal therapies is dependent on tissue management strategies even before formal hormonal receptor protein testing procedures. ${ }^{23}$

Khoury et $a l,{ }^{24}$ in their study of effects of delayed formalin fixation on 10 specimens that were kept at room temperature for $0,10,30 \mathrm{~min}$, and $1,2,4,8 \mathrm{~h}$ before fixation, concluded that ER expression began to decline after $2 \mathrm{~h}$ and PR expression after $1 \mathrm{~h}$ of cold ischemic time. Khoury et a ${ }^{24}$ also reported that at $8 \mathrm{~h}$ of cold ischemic time, ER expression was completely negative, and they recommended that specimens be fixed ideally within $1 \mathrm{~h}$ of receipt, and not to be stored overnight at $4{ }^{\circ} \mathrm{C}$. Their finding was that overnight storage at $4{ }^{\circ} \mathrm{C}$ yielded similar results to leaving specimens without fixation at room temperature for $8 \mathrm{~h}$. This finding is in contrast to our finding that non-refrigerated samples are affected more by prolonged cold ischemic time than refrigerated samples, whereas our finding of general decline in hormone receptor expression with increasing cold ischemic time periods is in keeping with their findings.

Apple et $a l^{25}$ studied the effect of pre-analytic variables of fixative type, fixation time, and 4 days of ischemic time on IHC accuracy for ER and PR. The authors stored an invasive lobular carcinoma specimen in a fresh state without any fixative in the refrigerator at $4{ }^{\circ} \mathrm{C}$ for 4 days (96 h) to assess the effect of prolonged ischemic time. After 4 days at $4{ }^{\circ} \mathrm{C}$, the tumor showed no degradation and no differences in the quality of tissue on ER and PR IHC staining. The same group of authors published another similar study to analyze the HER2 IHC and fluorescence in-situ hybridization results, and found that cold ischemic time of 4 days at $4{ }^{\circ} \mathrm{C}$ did not alter the HER2 results. ${ }^{25,26}$ It is important to note, however, that these two studies were performed on a single case of strongly hormone receptor-positive 


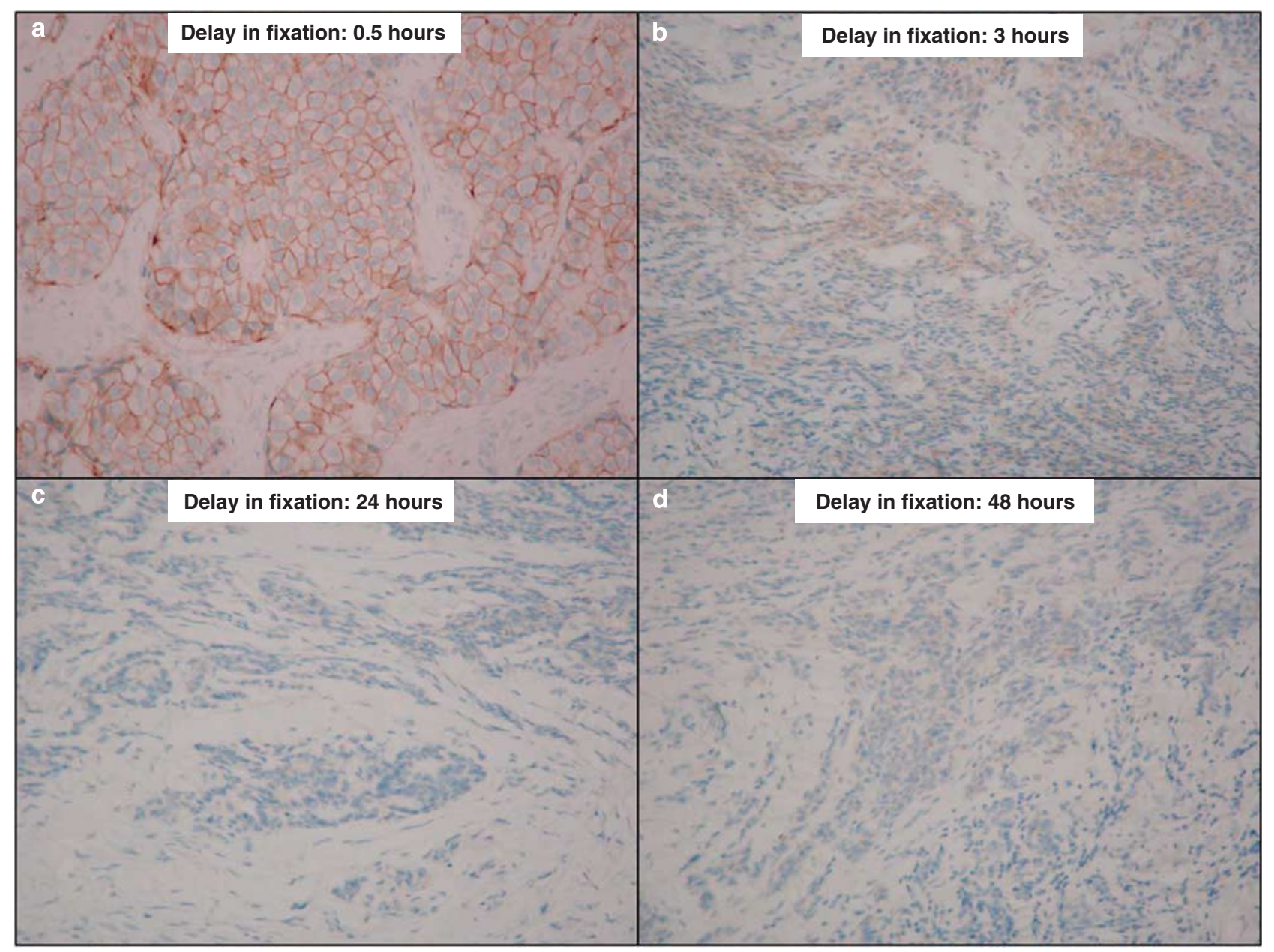

Figure 3 Same case as Figure 1. The tumor stained as '2+' for HER2 (same as core biopsy) at $0.5 \mathrm{~h}$ of delayed fixation (a), but demonstrated mild reduction in staining at $3 \mathrm{~h}(\mathbf{b})$ and was completely negative at $24 \mathrm{~h}(\mathbf{c})$ and $48 \mathrm{~h}(\mathbf{d})$. All photomicrographs were taken at $\times 200$.

Table 3 Average and median ER and PR H-scores for different cold ischemic time periods for refrigerated samples

\begin{tabular}{lcccc}
\hline $\begin{array}{l}\text { Cold } \\
\text { ischemic } \\
\text { time } \\
\text { period }(h)\end{array}$ & $\begin{array}{c}\text { ER H-score } \\
\text { (mean and } \\
\text { median) }\end{array}$ & $\begin{array}{c}\text { PR H-score } \\
\text { (mean and } \\
\text { median) }\end{array}$ & $\begin{array}{c}\text { ER H-score } \\
\text { compared } \\
\text { with core } \\
\text { (P-value) }\end{array}$ & $\begin{array}{c}\text { PR H-score } \\
\text { compared } \\
\text { with core } \\
\text { (P-value) }\end{array}$ \\
\hline 0.5 & $193 ; 230$ & $129 ; 150$ & 0.5608 & 0.9361 \\
1 & $200 ; 230$ & $128 ; 140$ & 0.7301 & 0.9092 \\
2 & $194 ; 220$ & $132 ; 170$ & 0.5762 & 0.9916 \\
3 & $190 ; 220$ & $120 ; 155$ & 0.4967 & 0.7244 \\
4 & $182 ; 215$ & $104 ; 80$ & 0.3365 & 0.3855 \\
24 & $159 ; 210$ & $100 ; 75$ & 0.1146 & 0.3356 \\
48 & $145 ; 160$ & $77 ; 20$ & 0.0637 & 0.1130 \\
\hline
\end{tabular}

tumor and on a single case of unequivocally HER2positive tumor. Therefore, the results are not applicable to most clinical specimens.

Qiu et $a 2^{27}$ looked into the effect of delayed formalin fixation on three different clones of ER (1D5, 6F11, and SP1) and PR (PgR636, 16, and 1E2) on the same group of cases as that of Khoury et al. ${ }^{24}$
Table 4 Average and median ER and PR H-scores for different cold ischemic time periods for non-refrigerated (at room temperature) samples

\begin{tabular}{lcccc}
\hline $\begin{array}{l}\text { Cold } \\
\text { ischemic } \\
\text { time } \\
\text { period }(h)\end{array}$ & $\begin{array}{c}\text { ER H-score } \\
\text { (mean and } \\
\text { median) }\end{array}$ & $\begin{array}{c}\text { PR H-score } \\
\text { (mean and } \\
\text { median) }\end{array}$ & $\begin{array}{c}\text { ER H-score } \\
\text { compared } \\
\text { with core } \\
\text { (P-value) }\end{array}$ & $\begin{array}{c}\text { PR } \text {-score } \\
\text { compared } \\
\text { with core } \\
\text { (P-value) }\end{array}$ \\
\hline 0.5 & $200 ; 230$ & $133 ; 160$ & 0.7180 & 0.9827 \\
1 & $195 ; 220$ & $122 ; 120$ & 0.6218 & 0.7875 \\
2 & $178 ; 210$ & $105 ; 60$ & 0.2858 & 0.4217 \\
3 & $146 ; 180$ & $87 ; 70$ & 0.0312 & 0.1448 \\
4 & $146 ; 170$ & $78 ; 50$ & 0.0389 & 0.0877 \\
24 & $115 ; 95$ & $68 ; 20$ & 0.0031 & 0.0467 \\
48 & $118 ; 90$ & $63 ; 20$ & 0.0049 & 0.0366 \\
\hline
\end{tabular}

They found that for ER, delayed formalin fixation's effect on SP1 was less than 1D5 and 6F11 clones. The SP1 clone had more intense nuclear staining, low background, and no cytoplasmic staining when compared with 1D5 and 6F11 clones. Similarly to $\mathrm{ER}$, it was found that delayed formalin fixation had 
negative effects on the number/percentage of positive cells and the intensity of the stain on all three PR clones. However, the difference among PR clones was not statistically significant. They concluded that regardless of the antibody clones evaluated, delayed formalin fixation has a negative effect on hormone receptors. ${ }^{27}$ In our study, we used SP1 as ER clone and $1 \mathrm{E} 2$ as $\mathrm{PR}$ clone. Improving the accuracy of hormone receptor and HER2 testing to increase the utility of ER, PR, and HER2 as prognostic/predictive markers in breast cancer is an ongoing challenge. Our study supports the benefit of minimizing cold ischemic time for proper assessment.

Apart from delay in fixation (focus of the current study), duration of formalin fixation is thought to affect receptor results. The duration of formalin fixation was not significantly altered in this study. However, in a separate study (article in press), we have shown that there is no significant difference in semi-quantitative IHC scores for ER/PR/HER2 in breast carcinomas that are fixed for up to $96 \mathrm{~h}$ compared with standard 8-48 h fixation. Therefore, we believe that duration of formalin fixation did not impact our current results.

The results of our study show that non-refrigerated samples are more prone to reduced IHC staining for prognostic/predictive markers than refrigerated samples. Cold ischemic time of as short as one-half hour may occasionally impact the IHC staining for PR. Significant reduction in IHC staining, however, generally does not result until $4 \mathrm{~h}$ for refrigerated samples and $2 \mathrm{~h}$ for nonrefrigerated samples. In light of our findings, it is best to keep cold ischemic time as minimal as possible and ASCO/CAP recommendation of $\leq 1 \mathrm{~h}$ is a prudent guideline to follow. However, we do realize that following this guideline will require change in practice at some institutions. The surgeons will be required to submit specimens promptly to pathology laboratories. To avoid delays in sectioning, surgeons should follow standard protocols for specimen orientation and pathology laboratories should adopt standard inking key. Another challenging task for the pathology laboratories would be to designate a pathology assistant for promptly processing breast specimens. Standardization of the pre-analytic variables is difficult but at the same time very important. Pathologists have always played a key role in performing prognostic/ predictive marker testing, but to achieve the goal of $\leq 1 \mathrm{~h}$ cold ischemic time will require a team approach.

\section{Acknowledgement}

We thank the Pathology Assistants at MageeWomens Hospital for specimen collection. We also thank Kim McManus HT (ASCP) for specimen processing and histology work.

\section{Disclosure/conflict of interest}

The authors declare no conflict of interest.

\section{References}

1 Liu S, Chia SK, Mehl E, et al. Progesterone receptor is a significant factor associated with clinical outcomes and effect of adjuvant tamoxifen therapy in breast cancer patients. Breast Cancer Res Treat 2010;119:53-61.

2 Mohsin SK, Weiss H, Havighurst T, et al. Progesterone receptor by immunohistochemistry and clinical outcome in breast cancer: a validation study. Mod Pathol 2004;17:1545-1554.

3 Fisher B, Redmond C, Brown A, et al. Treatment of primary breast cancer with chemotherapy and tamoxifen. N Engl J Med 1981;305:1-6.

4 Fisher B, Redmond C, Brown A, et al. Influence of tumor estrogen and progesterone receptor levels on the response to tamoxifen and chemotherapy in breast cancer. J Clin Oncol 1983;1:227-241.

5 Harris L, Fritsche H, Mennel R, et al. American Society of Clinical Oncology 2007 update of recommendations for the use of tumor markers in breast cancer. J Clin Oncol 2007;25:5287-5312.

6 Fitzgibbons PL, Page DL, Weaver D, et al. Prognostic factors in breast cancer: College of American Pathologists Consensus Statement 1999. Arch Pathol Lab Med 2000;124:966-978.

7 Early Breast Cancer Trialists' Collaborative Group E. Effects of chemotherapy and hormonal therapy for early breast cancer on recurrence and 15-year survival: an overview of the randomized trials. Lancet 2005;365:1687-1717.

8 Dowsett M, Allred C, Knox J, et al. Relationship between quantitative estrogen progesterone receptor expression human epidermal growth factor receptor 2 (HER-2) status with recurrence in the Arimidex, Tamoxifen, alone or in combination trial. J Clin Oncol 2008;26:1059-1065.

9 Press MF, Pike MC, Chazin VR, et al. Her-2/neu expression in node-negative breast cancer: direct tissue quantitation by computerized image analysis association of overexpression with increased risk of recurrent disease. Cancer Res 1993;53:4960-4970.

10 Press MF, Bernstein L, Thomas PA, et al. HER-2/neu gene amplification characterized by fluorescence in situ hybridization: Poor prognosis in node-negative breast carcinomas. J Clin Oncol 1997;15:2894-2904.

11 Yamauchi H, Stearns V, Hayes DF. When is a tumor marker ready for prime time? A case study of c-erbB-2 as a predictive factor in breast cancer. J Clin Oncol 2001;19:2334-2356.

12 Slamon DJ, Godolphin W, Jones LA, et al. Studies of the Her-2/neu proto-oncogene in human breast ovarian cancer. Science 1989;244:707-712.

13 Wolff AC, Hammond ME, Schwartz JN, et al. American Society of Clinical Oncology/College of American Pathologists guideline recommendations for human epidermal growth factor receptor 2 testing in breast cancer. Arch Pathol Lab Med 2007;131:18-43.

14 Bast RCJ, Ravdin P, Hayes DF, et al. 2000 update of recommendations for the use of tumor markers in breast colorectal cancer: clinical practice guidelines of the American Society of Clinical Oncology. J Clin Oncol 2001;19:1865-1878. 
15 Hammond ME, Hayes DF, Dowsett M, et al. American Society of Clinical Oncology/College of American Pathologists guideline recommendations for immunohistochemical testing of estrogen progesterone receptors in breast cancer. Arch Pathol Lab Med 2010;134:e48-e72.

16 Gown AM. Unmasking the mysteries of antigen or epitope retrieval formalin fixation. Am J Clin Pathol 2004;121:172-174.

17 Nenci I, Beccati MD, Piffanelli A, et al. Detection dynamic localisation of estradiol-receptor complexes in intact target cells by immunofluorescence technique. J Steroid Biochem 1976;7:505-510.

18 Diaz LK, Sneige N. Estrogen receptor analysis for breast cancer: current issues keys to increasing testing accuracy. Adv Anat Pathol 2005;12:10-19.

19 Yaziji H, Taylor CR, Goldstein NS, et al. Consensus recommendations on estrogen receptor testing in breast cancer by immunohistochemistry. Appl Immunohistochem Mol Morphol 2008;16:513-520.

20 Goldstein NS, Ferkowicz M, Odish E, et al. Minimum formalin fixation time for consistent estrogen receptor immunohistochemical staining of invasive breast carcinoma. Am J Clin Pathol 2003;120:86-92.

21 Flanagan MB, Dabbs DJ, Brufsky AM, et al. Histopathologic variables predict oncotype DX recurrence score. Mod Pathol 2008;21:1255-1261.
22 McCarty Jr KS, Miller LS, Cox EB, et al. Estrogen receptor analyses. Correlation of biochemical immunohistochemical methods using monoclonal antireceptor antibodies. Arch Pathol Lab Med 1985;109: 716-721.

23 Uy GB, Laudico AV, Carnate Jr JM, et al. Breast cancer hormone receptor assay results of core needle biopsy modified radical mastectomy specimens from the same patients. Clin Breast Cancer 2010;10: 154-159.

24 Khoury T, Sait S, Hwang H, et al. Delay to formalin fixation effect on breast biomarkers. Mod Pathol 2009;22:1457-1467.

25 Apple S, Pucci R, Lowe AC, et al. The effect of delay in fixation different fixatives, duration of fixation in estrogen progesterone receptor results in breast carcinoma. Am J Clin Pathol 2011;135:592-598.

26 Moatamed NA, Nanjangud G, Pucci R, et al. Effect of ischemic time fixation time, fixative type on HER2/neu immunohistochemical fluorescence in situ hybridization results in breast cancer. Am J Clin Pathol 2011;136:754-761.

27 Qiu J, Kulkarni S, Chandrasekhar R, et al. Effect of delayed formalin fixation on estrogen progesterone receptors in breast cancer: a study of three different clones. Am J Clin Pathol 2010;134:813-819. 